\title{
Inducing some Morphological Variations in Cyperus alternifolius L. by Using Gamma Irradiation
}

\author{
Magd el Din F. Rida \\ Antoniades Research Branch Alexandria, Ornamental Plants Research and Landscape \\ Gardening Department, Horticulture Research Institute, ARC, Egypt.
}

\begin{abstract}
This study was conducted during 2015, 2016 and 2017 seasons at Antoniades Research Branch, Horticulture Research Institute, Ministry of Agriculture, Alexandria. The aim of the present study was to study the effects of different doses of gamma rays from Cobalt -60 on Cyperus alternifolius $\mathrm{L}$. plants Rhizomes of Cyprus plants were irradiated with six doses of gamma irradiation $(0.0,20,40,60,80$ and 100 Gray). The results showed that irradiation of rhizomes with 20 Gray caused the highest increase in sprouting percentage and rate while the 100 gray treatment caused the lowest survival percentage in M1 -generation. The 100 Gray treatment caused the lowest significant decrease in all studied vegetative growth parameters in M1 and M2 generations. As for the vegetative growth abnormalities, the application of gamma rays at the dose of 100 Gray resulted in dwarf plants in M1 and M2 generations. While using 40 Gray caused 3 regenerated small plants from leaves internode and 60 Gray caused 1 regenerated small plant from leaves internodes in M1 -generation, this abnormality disappeared in the M2 -generation. Application of restriction fragment length polymorphism (RFLP) analysis on three Cyperus alternifolius generations stressed with 60 and 100 Gray comparing with un-irradiated Cyperus alternifolius cleared that radiation dose (100 Gray) reflected the dramatic increase of genetic polymorphism and first generation reflected the highest radiation influence on polymorphism.
\end{abstract}

Key wards: Gamma rays - Cyperus alternifolius L - Vegetative growth abnormalities -Dwarf plants - RFLP analysis

\section{INTRODUCTION}

Cyperus alternifolius L. (Umbrella palm), the plant belongs to the family Cyperaceae. It is native to Madagascar but is frequently cultivated worldwide. It is an aquatic plant and growing in still or slow-moving water. It is mainly cultivated for its decorative use in water gardens and at the margins of pools or ponds or as a pot plant. it is also sold as cut foliage in the wholesale flower markets (Kyambadde et al., 2004).

Mutation is a sudden heritable change in the DNA in a living cell, not caused by genetic segregation or genetic recombination (Van Harten, 1998). It occurs in natural population but at a very low rate which called spontaneous mutation, while mutation can be induced by applying chemical or physical mutagen which is called induced mutation. Changes which are a result of an induced mutation in crop improvement program is known as mutation breeding. For asexually propagated crops mutation breeding is a useful tool for improving this plant. Somatic mutant can easily be created in this type of plants, propagated and directly used any phenotypic effect of chromosomal arrangement may be utilized due to the vegetative mode of reproduction ( Dipak and Soma , 2010). 
At the beginning of the $20^{\text {th }}$ century first, artificial induced mutant was done by ionizing radiation. One of these ionizing radiation is gamma radiation. The main effect of gamma irradiation is based on the interaction with atoms or molecules in the cell especially with water to produce free radical in cells; this radical can damage or modify important parts of the plant which causes changes in morphology, biochemistry or physiology of plants. (Dipak and Soma , 2010). Recently, molecular biology methodologies present a huge help to rapidly identify varied numbers of heterozygous genetic markers within a single plant genera. Reaction-Restriction Fragment Length Polymorphism (RFLP) is considered to be a PCR depending method with adding enzymes after the DNA amplification. Thus it may give a more specific result (Brasch et al., 2010 and Mirzahoseini et al., 2009). Thus, molecular techniques such (RFLP) could reflect the genetic diversity and similarity among plant cultivars which caused by different mutant agents like, biochemical mutagenesis, radiation, ...ect.

The main objective of the present research was to study the effect of different doses of gamma rays from Cobalt -60 on Cyperus alternifolius L. rhizomes and the possibility of inducing variation which may be of ornamental value.

\section{MATERIALS AND METHODS}

A pot experiment was carried out at Antoniades Research Branch, Horticulture Research Institute, A.R.C. Alexandria during the seasons of 2015, 2016 and 2017 . Rhizomes of local Cyperus plants with an average weight of 25 $\mathrm{g}$ and had at least 8-10 buds were exposed to six doses of gamma rays $(0.0,20$, 40 , 60 , 80 and 100 Gray). Eighteen rhizomes were used for each dose. The irradiated rhizomes (one rhizome / pot) were planted in clay pots of $25 \mathrm{~cm}$ diameter containing medium consisted of ( $1: 1 \mathrm{v} / \mathrm{v})$ clay and sand on March 2015 for the $\mathrm{M}_{1}$ generation. On March 2016, the rhizomes produced at the end of the $M_{1}$ generation were used to produce $\left(M_{2}\right.$ generation). On March 2017 , at the end of $\mathrm{M}_{2}$ generation, rhizomes of control plants stressed plants with a moderate dose of radiation 60 Gray and high radiation doses 100 Gray) were planted for the $\mathrm{M}_{3}$ generation.

Gamma rays used for this experiment were generated from Cobalt-60 source at the National Center for Radiation Research and Technology, Atomic Energy Authority Nasr City, Cairo, Egypt. Irradiation treatment were carried out in March 2015.

\section{The following data were recorded}

1-Sprouting data : which recorded for the M1 generation (1-1)Sprouting percentage (\%)

It was calculated according to the following formula

Sprouting percentage $(\%)=\frac{\text { number of sprouted } \text { rhizomes }}{\text { total rhizome number }} X 100$ after 10 days of planting. 


\section{(1-2)Sprouting rate (SR)}

It was calculated according to the following formula of (Mahmoud,2013):

Sprouting rate $(\mathrm{SR})=\frac{\boldsymbol{a}+(\boldsymbol{a}+\boldsymbol{b})+(\boldsymbol{a}+\boldsymbol{b}+\boldsymbol{c})+\cdots+(\boldsymbol{a}+\boldsymbol{b}+\boldsymbol{c}+\boldsymbol{m})}{\boldsymbol{n}(\boldsymbol{a}+\boldsymbol{b}+\boldsymbol{c}+\boldsymbol{m})}$

Where $a, b, c$ are the number of sprouted rhizomes in the first, second and third count, $\mathrm{m}$ is number of sprouted rhizomes in the final count, $\mathrm{n}$ is the number of counts.

\section{2- Survival percentage (\%)}

It was determined for M1 generation according to the following formula Survival percentage $(\%)=\frac{\text { number of survived rhizomes }}{\text { total rhizome number }} X 100$ after 60 days of planting.

3- The flowing vegetative growth parameters were recorded for the M1 and M2 generations:

Plant height $(\mathrm{cm})$, number of stems / rhizome, stem's diameter $(\mathrm{cm})$, Dry weight of vegetative growth $(\mathrm{g})$, leaf bract's number / stem, leaf bract's width $(\mathrm{cm})$ and leaf bract's area $\left(\mathrm{cm}^{2}\right)$.

\section{4- Chemical analysis:}

Chlorophyll $\mathrm{a}$ and $\mathrm{b}$ content (mg/100 $\mathrm{g}$ fresh weight) in $\mathrm{M} 1$ and $\mathrm{M} 2$ generations was determined according to (Moran, 1982)

\section{5-Phenotypic changes in M1 and M2- generations}

were observed (growth habit, leaf form, leaf number and dwarfism).

\section{6- RFLP analysis}

This investigation was carried out to monitor and detect the influence of radiations doses on Cyperus alternifolius. RFLP fingerprinting method was applied on three Cyperus alternifolius generations stressed with moderate and high radiation doses (60 and 100 Gray) comparing with un-irradiated Cyperus alternifolius sample.

(6-1) Genomic DNA extraction:

Total genomic DNA was extracted and purified from nine Cyperus alternifolius through E.Z.N.A.® plant DNA kit, D3485-01 (Omega Bio- TEK, USA) according to manufacturer protocol.

\section{(6-2) PCR reaction.}

Amplification of $r p L 32-t r n L$ ( Table 1) was performed following the protocol and using the primers of Shaw et al ., (2007). Then, EcoRI (10 U/ $\mu \mathrm{L})$, ER0271, Thermo Fisher Scientific, (USA) restriction endonucleases were used to identify radiation doses for Cyperus alternifolius. Ten $\mu \mathrm{l}$ of the PCR mixture was digested using 10 units of the restriction enzyme at $37^{\circ} \mathrm{C}$ for $12 \mathrm{~h}$. Restriction fragments were separated on a $1.5 \%$ agarose gel for $1.5 \mathrm{~h}$ at $90 \mathrm{~V}$. DNA fragments were observed and photographed under UV illumination. The sizes of the DNA bands were compared to DNA markers run on the same gel.

Table (1) . rpL32 and trnL primers features

\begin{tabular}{cc}
\hline Primers & Sequences \\
$r p L 32$ & $(5-C A G T T C C A A A A A A A C G T A C T T C-3)$ \\
$t r n L$ & $(5-C T G C T T C C T A A G A G C A G C G T-3)$ \\
\hline
\end{tabular}




\section{Statistical Analysis}

The experiment layout was designed to provide complete randomized block design, which contained three replicates, each replicate contained six treatments of gamma ray doses. Six pots were used as an experimental unit for each treatment in each replicate. The means of the individual factors and their interactions were compared by L.S.D. at $5 \%$ level of probability according to (Snedecor and Cochran, 1989). The coefficient of variation (C.V.) was calculated according to the following formula (Dipak and Soma, 2010)

$$
\text { C.V. }=\frac{\text { Standard devision }}{\text { Mean }} \times 100
$$

\section{RESULTS}

1-Effect of gamma irradiation on sprouting percentage (\%), sprouting rate, and survival percentage (\%)during M1- generation.

Data in Table (2) showed that the highest sprouting percentage $(95 \%)$ was obtained after application of 20 Gray of gamma rays followed by the untreated rhizomes $(84.21 \%)$. While the lowest sprouting percentage $(11.11 \%)$ was recorded after irradiation of rhizomes with 100 Gray .For sprouting rate Table (2) cleared that the highest sprouting rate $(0.98)$ was observed after irradiation of rhizomes with 20 Gray. The lowest sprouting rate (0.76) was obtained after application of 100 Gray. Also, Table (2) cleared that the survived rhizomes after 60 days of planting recorded $83.33 \%$ with application of 100 Gray.

Table (2). Sprouting percentage (\%), sprouting rate and survival percentage (\%) of rhizomes of Cyperus alternifolius as affected by different gamma ray doses during M1- generation

\begin{tabular}{cccc}
\hline $\begin{array}{c}\text { Gamma ray } \\
\text { dose (Gray) }\end{array}$ & $\begin{array}{c}\text { Sprouting } \\
\text { percentage } \\
\mathbf{( \% )}\end{array}$ & $\begin{array}{c}\text { Sprouting } \\
\text { rate }\end{array}$ & $\begin{array}{c}\text { Survival } \\
\text { percentage } \\
\mathbf{( \% )}\end{array}$ \\
\hline $\mathbf{0 . 0}$ & 84.21 & 0.93 & 100.00 \\
$\mathbf{2 0}$ & 95.00 & 0.98 & 100.00 \\
$\mathbf{4 0}$ & 66.67 & 0.88 & 100.00 \\
$\mathbf{6 0}$ & 61.11 & 0.86 & 100.00 \\
$\mathbf{8 0}$ & 77.78 & 0.91 & 100.00 \\
$\mathbf{1 0 0}$ & 11.11 & 0.76 & 83.33 \\
\hline
\end{tabular}

2- Effect of gamma irradiation on vegetative growth parameters in the M1 and M2 generations:

Data in Table (3) showed that there was a significant difference between treatments in the mean value of plant height, number of stem/rhizome, stem's diameter and dry weight of vegetative growth of Cyperus alternifolius plants as affected by the different doses of gamma rays in the M1 and M2 generations. 
It is also observed from Table (3) that irradiation rhizomes with 100 Gray caused the highest significant reduction of plant height, number of stem/rhizome, stem diameter and dry weight of vegetative growth, this reduction continued in the late effect of gamma rays (M2).

While, irradiation of the rhizomes with 20 and 80 Gray caused significant increase in plant height in the M1 generation this increment was in the same level of significance with control plant in M2 generation. For the number of stems per rhizome, the data in Table (3) cleared that in the M2 generation, the highest significant increase was obtained after irradiation with 40 and 60 Gray. Moreover, Table (3) showed that the high thickness of stem was obtained after application of 20, 60 and 0.0 Gray in the M1 generation and the control plant in the M2 generation. The highest significant increase of dry weight was recorded after irradiation with 20, 40 and 60 Gray in the M1 generation while in the M2 generation the increase in dry weight was obtained after application of 20, 40, 60and 80 Gray in the same level of significance with control plant.

A wide range of variability was observed in plants derived from rhizomes treated with different doses of gamma rays, the variability as estimated by coefficient of variation (Table 3 ) cleared that coefficient of variation was more than control for plant height and the number of stem /rhizome for all treatments, the treatments 20 and 60 Gray for stem diameter and treatment 20, 40 and 80 Gray for vegetative dry weight in M1 generation. For M2 generation ,the coefficient of variation was more than control for the number of stem /rhizome and vegetative dry weight for all treatments the treatments $20,60,80$ and 100 Gray for plant height and the treatments 80 and 100 for stem diameter. This observation indicates that the individual plant of the same genotype of Cyperus alternifolius differs in the rate of effect after gamma ray treatment.

As for leaf bract characteristics, data in Table (4) indicated that there was a significant difference between treatments in the mean value of leaf bract's number / stem, leaf bract's width and leaf bract's area of Cyperus alternifolius plants after application of different doses of gamma rays in M1 and M2 generations.

Data presented in Table (4) showed that the highest significant decrease in the mean value of leaf bract's number/stem, leaf bract's width and leaf bract's area was obtained after application of gamma ray at the dose of 100 Gray in M1 and M2 generations .

A marked increase of leaf bract's number/stem was observed after irradiation with 80 Gray in the M1 and M2 generations with the same level of significance of control plant. For leaf bract's width and leaf bract's area, data in Table (4) showed that rhizome treatment with 20,60 and 80 Gray caused the highest significant increase with the same level of untreated control in the M1 generation this increment continued in the M2 generation for leaf bract's width after application of 80 Gray while for leaf bract's area the highest significant increase was obtained of untreated plants. The coefficient of variation of leaf bract's number / stem was more than control for all gamma ray doses in the M1 
generation while the coefficient of variation after irradiation with 40,60,80 and 100 Gray was less than the control in the M2 generation. For leaf bract's width and leaf bract's area coefficient of variation after rhizome irradiation with 40,60,80 and 100 Gray was less than the control in M1 generation.

Table (3). Average and coefficient of variation (C.V.) of plant height ( $\mathrm{cm}$ ), number of stems / rhizome, stem's diameter $(\mathrm{cm})$ and Dry weight of vegetative growth $(\mathrm{g})$ of Cyperus alternifolius derived from irradiated rhizomes by different gamma ray doses during M1 and M2 generations

\begin{tabular}{|c|c|c|c|c|c|c|c|}
\hline \multirow[b]{2}{*}{ The parameters } & \multirow[b]{2}{*}{$\begin{array}{l}\text { Gamma ray } \\
\text { Doses (Gray) }\end{array}$} & \multicolumn{3}{|c|}{ M1 } & \multicolumn{3}{|c|}{ M2 } \\
\hline & & Average & C.V. & $\frac{C . V . d o s e}{C . V . \operatorname{cont} t}$ & Average & C.V. & $\frac{C . V . d o s e}{C . V . \operatorname{cont}}$ \\
\hline \multirow{7}{*}{$\begin{array}{l}\text { Plant height } \\
\text { (cm) }\end{array}$} & 0.0 & $46.47 \mathrm{~b}$ & 5.14 & 1.00 & $62.93 \mathrm{a}$ & 7.78 & $\frac{\text { C.V.cont }}{1.00}$ \\
\hline & 20 & $52.20 \mathrm{a}$ & 8.79 & 1.71 & $61.80 \mathrm{a}$ & 12.78 & 1.64 \\
\hline & 40 & $41.07 \mathrm{c}$ & 9.00 & 1.75 & $56.00 \mathrm{~b}$ & 6.23 & 0.80 \\
\hline & 60 & $42.07 \mathrm{c}$ & 7.04 & 1.37 & $56.93 b$ & 9.27 & 1.19 \\
\hline & 80 & $49.20 \mathrm{a}$ & 8.30 & 1.62 & $64.53 \mathrm{a}$ & 11.02 & 1.42 \\
\hline & 100 & $24.33 d$ & 13.44 & 2.62 & $39.25 \mathrm{c}$ & 15.60 & 2.01 \\
\hline & L.S.D.at 0.05 & 4.10 & & & 4.38 & & \\
\hline \multirow{7}{*}{$\begin{array}{l}\text { Number } \\
\text { of stems / } \\
\text { rhizome }\end{array}$} & 0.0 & $34.13 a$ & 9.88 & 1.00 & $32.87 d$ & 13.03 & 1.00 \\
\hline & 20 & $43.80 \mathrm{a}$ & 17.72 & 1.79 & $42.07 \mathrm{~b}$ & 15.60 & 1.20 \\
\hline & 40 & $42.87 a$ & 12.39 & 1.25 & $51.13 \mathrm{a}$ & 13.26 & 1.02 \\
\hline & 60 & $41.80 \mathrm{a}$ & 15.72 & 1.59 & $53.20 \mathrm{a}$ & 21.09 & 1.62 \\
\hline & 80 & $37.60 \mathrm{a}$ & 10.22 & 1.03 & $37.20 \mathrm{c}$ & 15.69 & 1.20 \\
\hline & 100 & $16.47 \mathrm{~b}$ & 11.53 & 1.17 & $37.91 \mathrm{c}$ & 27.24 & 2.09 \\
\hline & L.S.D.at 0.05 & 10.39 & & & 2.47 & & \\
\hline \multirow{7}{*}{$\begin{array}{l}\text { Stem's diameter } \\
\text { (cm) }\end{array}$} & 0.0 & $0.32 \mathrm{a}$ & 0.048 & 1.00 & $0.44 \mathrm{a}$ & 0.077 & 1.00 \\
\hline & 20 & $0.33 a$ & 0.057 & 1.20 & $0.38 \mathrm{~b}$ & 0.075 & 0.97 \\
\hline & 40 & $0.29 \mathrm{~b}$ & 0.043 & 0.89 & $0.31 \mathrm{c}$ & 0.068 & 0.89 \\
\hline & 60 & $0.31 a b$ & 0.049 & 1.02 & $0.26 \mathrm{c}$ & 0.064 & 0.84 \\
\hline & 80 & 0.29 b & 0.036 & 0.75 & $0.37 \mathrm{~b}$ & 0.082 & 1.07 \\
\hline & 100 & $0.19 c$ & 0.047 & 0.97 & $0.28 \mathrm{c}$ & 0.093 & 1.21 \\
\hline & L.S.D.at 0.05 & 0.03 & & & 0.05 & & \\
\hline \multirow{7}{*}{$\begin{array}{l}\text { Dry weight of } \\
\text { vegetative } \\
\text { growth ( g) }\end{array}$} & 0.0 & $26.32 \mathrm{~b}$ & 6.57 & 1.00 & $53.60 \mathrm{a}$ & 9.63 & 1.00 \\
\hline & 20 & $32.11 \mathrm{a}$ & 8.70 & 1.32 & $54.86 \mathrm{a}$ & 19.41 & 2.02 \\
\hline & 40 & $29.21 \mathrm{a}$ & 9.38 & 1.43 & $54.64 \mathrm{a}$ & 17.00 & 1.76 \\
\hline & 60 & 25.92 b & 6.44 & 0.98 & 56.57 a & 13.43 & 1.39 \\
\hline & 80 & $29.07 a b$ & 9.52 & 1.45 & $54.70 \mathrm{a}$ & 11.92 & 1.24 \\
\hline & 100 & $5.49 \mathrm{c}$ & 5.06 & 0.77 & $28.86 \mathrm{~b}$ & 22.38 & 2.32 \\
\hline & L.S.D.at 0.05 & 3.18 & & & 10.11 & & \\
\hline
\end{tabular}

L.S.D. at $0.05=$ Least significant different at 0.05 level of probability

Means of treatments in the column have the same letters, are not significantly different at $5 \%$ level.

C.V. = Coefficient of Variation

Moreover, in the M2 generation, the coefficient of variation was more than the control for the plants treated with 40,60,80 and 100 Gray in the leave bract's width and 20,60,80 and 100 Gray for leaf bract's area. This observed variability indicates that the individual plant of the same genotype of Cyperus alternifolius differs in the rate of effect after gamma ray treatment . 
Table (4). Average and coefficient of variation (C.V.) of leaf bract's number I stem , leaf bract's width $(\mathrm{cm})$ and leaf bract's area of Cyperus alternifolius derived from irradiated rhizomes by different gamma ray doses during the M1 and M2 generations

\begin{tabular}{|c|c|c|c|c|c|c|c|}
\hline \multirow{3}{*}{ The parameters } & \multirow{3}{*}{$\begin{array}{c}\text { Gamma ray } \\
\text { doses (Gray) }\end{array}$} & \multicolumn{3}{|c|}{ M1 } & \multicolumn{3}{|c|}{ M2 } \\
\hline & & Average & c. V & C.V.dose & Average & $c y$ & C.V.dose \\
\hline & & Rverage & & $\overline{C . V . c o n t}$. & Avelage & C.v. & $\overline{C . V . c o n t}$. \\
\hline \multirow{7}{*}{$\begin{array}{l}\text { Leaf bract's } \\
\text { number / stem }\end{array}$} & 0.0 & $11.29 \mathrm{a}$ & 1.39 & 1.00 & $12.18 \mathrm{a}$ & 1.94 & 1.00 \\
\hline & 20 & $10.83 a$ & 1.51 & 1.09 & $10.74 b$ & 1.94 & 1.00 \\
\hline & 40 & $9.35 a b$ & 1.66 & 1.19 & $11.15 a b$ & 1.42 & 0.73 \\
\hline & 60 & $9.29 \mathrm{~b}$ & 2.16 & 1.56 & $9.90 \mathrm{~b}$ & 1.35 & 0.70 \\
\hline & 80 & $11.50 \mathrm{a}$ & 5.19 & 3.73 & $12.33 \mathrm{a}$ & 1.85 & 0.96 \\
\hline & 100 & $8.54 \mathrm{~b}$ & 1.52 & 1.09 & $8.56 \mathrm{~b}$ & 1.63 & 0.84 \\
\hline & L.S.D.at 0.05 & 1.94 & & & 1.42 & & \\
\hline \multirow{7}{*}{$\begin{array}{l}\text { Leaf bract's } \\
\text { width }(\mathrm{cm})\end{array}$} & 0.0 & $0.69 a$ & 0.147 & 1.00 & $0.92 \mathrm{a}$ & 0.106 & 1.00 \\
\hline & 20 & $0.68 a$ & 0.252 & 1.72 & $0.73 b$ & 0.073 & 0.69 \\
\hline & 40 & $0.56 \mathrm{~b}$ & 0.127 & 0.86 & $0.72 b c$ & 0.141 & 1.33 \\
\hline & 60 & $0.68 a$ & 0.124 & 0.85 & $0.64 \mathrm{c}$ & 0.135 & 1.27 \\
\hline & 80 & $0.74 \mathrm{a}$ & 0.139 & 0.95 & $0.82 a b$ & 0.176 & 1.65 \\
\hline & 100 & $0.35 \mathrm{c}$ & 0.111 & 0.76 & $0.59 \mathrm{c}$ & 0.210 & 1.98 \\
\hline & L.S.D.at 0.05 & 0.09 & & & 0.11 & & \\
\hline \multirow{7}{*}{$\begin{array}{l}\text { Leaf bract's area } \\
\qquad\left(\mathrm{cm}^{2}\right)\end{array}$} & 0.0 & $11.26 \mathrm{a}$ & 4.87 & 1.00 & $14.92 \mathrm{a}$ & 3.10 & 1.00 \\
\hline & 20 & $10.25 a$ & 5.22 & 1.07 & $11.92 \mathrm{c}$ & 3.67 & 1.18 \\
\hline & 40 & $6.92 \mathrm{~b}$ & 2.97 & 0.61 & $9.76 \mathrm{~d}$ & 3.51 & 1.13 \\
\hline & 60 & $10.16 \mathrm{a}$ & 3.20 & 0.66 & $10.15 d$ & 2.75 & 0.89 \\
\hline & 80 & $11.64 \mathrm{a}$ & 4.42 & 0.91 & $13.57 \mathrm{~b}$ & 4.10 & 1.32 \\
\hline & 100 & $3.51 \mathrm{~b}$ & 1.64 & 0.34 & $7.93 \mathrm{e}$ & 4.43 & 1.43 \\
\hline & L.S.D.at 0.05 & 2.14 & & & 0.80 & & \\
\hline
\end{tabular}

L.S.D. at $0.05=$ Least significant different at 0.05 level of probability

Means of treatments in the column have the same letters, are not significantly different at $5 \%$ level.

C.V. = Coefficient of Variation

\section{3-Effect of gamma irradiation on leaf chlorophyll content in the M1 and M2 generations:}

As for the leaves, chlorophyll content data in Table (5) indicated that there was a significant difference between treatments in the mean value of Chlorophyll a and Chlorophyll b of Cyperus alternifolius plants after application of different doses of gamma rays in M1 and M2 generations.

Also, Table (5) showed that the application of gamma ray at the dose of 0 . 20 Gray caused the highest significant increase in the mean value of chlorophyll a, while the lowest significant was obtained from rhizome treatment with 40,60, 80 and 100 Gray. For the late effect of gamma ray (M2), Table (5) showed that the highest significant increase of chlorophyll a was obtained after application of 80 Gray with the same level significant of application of 100 and 40 Gray.

As for chlorophyll b content, Table (5) cleared that the application of gamma ray at 60 Gray in the M1 caused the highest significant decrease in the amount of chlorophyll b while in the M2 -generation, the application of gamma 
ray at 80 and 100 gray caused significant increase in chlorophyll b content compared to the control plants

All treatments caused a decrement in the coefficient of variation for chlorophyll a in M1- generation and 20, 80 and 100 Gray in M2-generation. While the coefficient of variation for chlorophyll $b$ was more than control after irradiation with 80 in the M1-generation and the coefficient of variation for chlorophyll $b$ was more than control after irradiation with all gamma ray doses in M2-generation.

Table (5). Average and coefficient of variation (C.V.) Chlorophyll a and Chlorophyll $b(\mathrm{mg} / \mathrm{g}$ leaves fresh weight) of Cyperus alternifolius derived from irradiated rhizomes by different gamma ray doses during M1 and M2 generations

\begin{tabular}{|c|c|c|c|c|c|c|c|}
\hline \multirow[b]{2}{*}{ The parameters } & \multirow{2}{*}{$\begin{array}{l}\text { Gamma ray } \\
\text { doses (Gray) }\end{array}$} & \multicolumn{3}{|c|}{ M1 } & \multicolumn{3}{|c|}{ M2 } \\
\hline & & Average & C.V. & $\frac{C \cdot V \cdot d o s e}{C \cdot V \cdot \text { cont }}$ & Average & C.V. & $\frac{C . V . d o s e}{C \cdot V \cdot \text { cont }}$ \\
\hline \multirow{7}{*}{$\begin{array}{l}\text { Chlorophyll a } \\
\text { ( } \mathrm{mg} / \mathrm{g} \text { leaves } \\
\text { fresh weight) }\end{array}$} & 0.0 & $1.57 \mathrm{a}$ & 0.16 & 1.00 & $0.70 c$ & 0.04 & 1.00 \\
\hline & 20 & $1.66 \mathrm{a}$ & 0.07 & 0.45 & $0.72 c$ & 0.12 & 2.95 \\
\hline & 40 & $0.86 \mathrm{~b}$ & 0.09 & 0.60 & $0.92 a b$ & 0.03 & 0.64 \\
\hline & 60 & $0.71 \mathrm{~b}$ & 0.02 & 0.15 & $0.83 b c$ & 0.12 & 3.03 \\
\hline & 80 & $0.81 \mathrm{~b}$ & 0.12 & 0.78 & $1.02 \mathrm{a}$ & 0.02 & 0.57 \\
\hline & 100 & $0.82 \mathrm{~b}$ & 0.16 & 0.99 & $0.93 a b$ & 0.05 & 1.26 \\
\hline & L.S.D.at 0.05 & 0.20 & & & 0.15 & & \\
\hline \multirow{7}{*}{$\begin{array}{l}\text { Chlorophyll b } \\
\text { (mg/g leaves } \\
\text { fresh weight) }\end{array}$} & 0.0 & $0.36 \mathrm{a}$ & 0.15 & 1.00 & $0.20 \mathrm{~b}$ & 0.02 & 1.00 \\
\hline & 20 & $0.61 a$ & 0.13 & 0.84 & $0.35 a b$ & 0.11 & 7.02 \\
\hline & 40 & $0.38 \mathrm{a}$ & 0.12 & 0.78 & $0.50 a$ & 0.13 & 8.08 \\
\hline & 60 & $0.05 \mathrm{~b}$ & 0.01 & 0.02 & $0.35 a b$ & 0.04 & 2.74 \\
\hline & 80 & $0.52 \mathrm{a}$ & 0.26 & 1.72 & $0.52 a$ & 0.02 & 1.10 \\
\hline & 100 & $0.56 \mathrm{a}$ & 0.03 & 0.22 & $0.41 a$ & 0.06 & 3.47 \\
\hline & L.S.D.at 0.05 & 0.30 & & & 0.17 & & \\
\hline
\end{tabular}

L.S.D. at $0.05=$ Least significant different at 0.05 level of probability

Means of treatments in the column have the same letters, are not significantly different at $5 \%$ level. C.V. = Coefficient of Variation

\section{4-Effect of radiation on the induction of variation (plant abnormalities) in the M1 and M2 -generations}

Table (6) cleared that the application of gamma rays at the dose of 100 Gray caused dwarfism to $47 \%$ of M1 - generation plants this dwarfism was observed at the percentage of $28 \%$ of $\mathrm{M} 2$ plants. The dwarfism of plants was cleared as short of plant height, thinner of leave bract's and less leave bract's number (Photo1).

Also, it is observed from Table (6) and Photo (1-C) that application of gamma ray at moderate dose caused regeneration of small plants from leaf internodes at the percentage of 17 for 40 Gray and $0.06 \%$ for 60 Gray in the M1generation. This abnormality disappeared in the M2-generation. 
Table (6). Percentage of plant variation (abnormalities) of Cyperus alternifolius $\mathrm{L}$ derived from irradiated rhizomes by different gamma ray doses during $\mathrm{M} 1$ and $\mathrm{M} 2$ generations

\begin{tabular}{ccccccccc}
\hline \multirow{2}{*}{$\begin{array}{c}\text { Gamma ray } \\
\text { doses } \\
\text { (Gray) }\end{array}$} & \multicolumn{7}{c}{ Type of variation (abnormalities) } \\
\cline { 2 - 9 } & \multicolumn{7}{c}{ Dwarf plants } & \multicolumn{5}{c}{$\begin{array}{c}\text { Regeneration of small plants from leaf } \\
\text { internodes }\end{array}$} \\
\cline { 2 - 9 } & M1- generation & M2- generation & M1-generation & M2-generation \\
\cline { 2 - 9 } & No & $\%$ & No & $\%$ & No & $\%$ & No & $\%$ \\
\hline $\mathbf{0 . 0}$ & 0 & 0 & 0 & 0 & 0 & 0 & 0 & 0 \\
$\mathbf{2 0}$ & 0 & 0 & 0 & 0 & 0 & 0 & 0 & 0 \\
$\mathbf{4 0}$ & 0 & 0 & 0 & 0 & 3 & 17 & 0 & 0 \\
$\mathbf{6 0}$ & 0 & 0 & 0 & 0 & 1 & 0.06 & 0 & 0 \\
$\mathbf{8 0}$ & 0 & 0 & 0 & 0 & 0 & 0 & 0 & 0 \\
$\mathbf{1 0 0}$ & 8 & 47 & 5 & 28 & 0 & 0 & 0 & 0 \\
\hline
\end{tabular}

Dwarf plants was expressed as the plants height less than half of the average plant height of control plant

\section{5- RFLP analysis}

Genetic variation was detected and evaluated via Restriction fragment length polymorphism (RFLP) and computerized analysis for three generations of Cyperus alternifolius under different radiation doses (as shown by Photo 2).

Data in Table (7) showed that the highest radiation dose (100 Gray) reflected the dramatic increase of genetic polymorphism (64.5\% Polymorphism ) for Cyperus alternifolius comparing with un-irradiated sample and radiation with 60 Gray which showed insignificant influence ( $44.4 \%$ and $37.5 \%$ Polymorphism, respectively). Furthermore, Table (8) cleared that the first generation reflected the highest radiation influence $(54.8 \%$ of the average of polymorphism) comparing with second and third generations $(47.2 \%$ and $39.6 \%$ of the average of polymorphism). Phyllogenetic tree was constructed for three generations of Cyperus alternifolius treated with different radiation doses based on Restriction fragment length polymorphism 


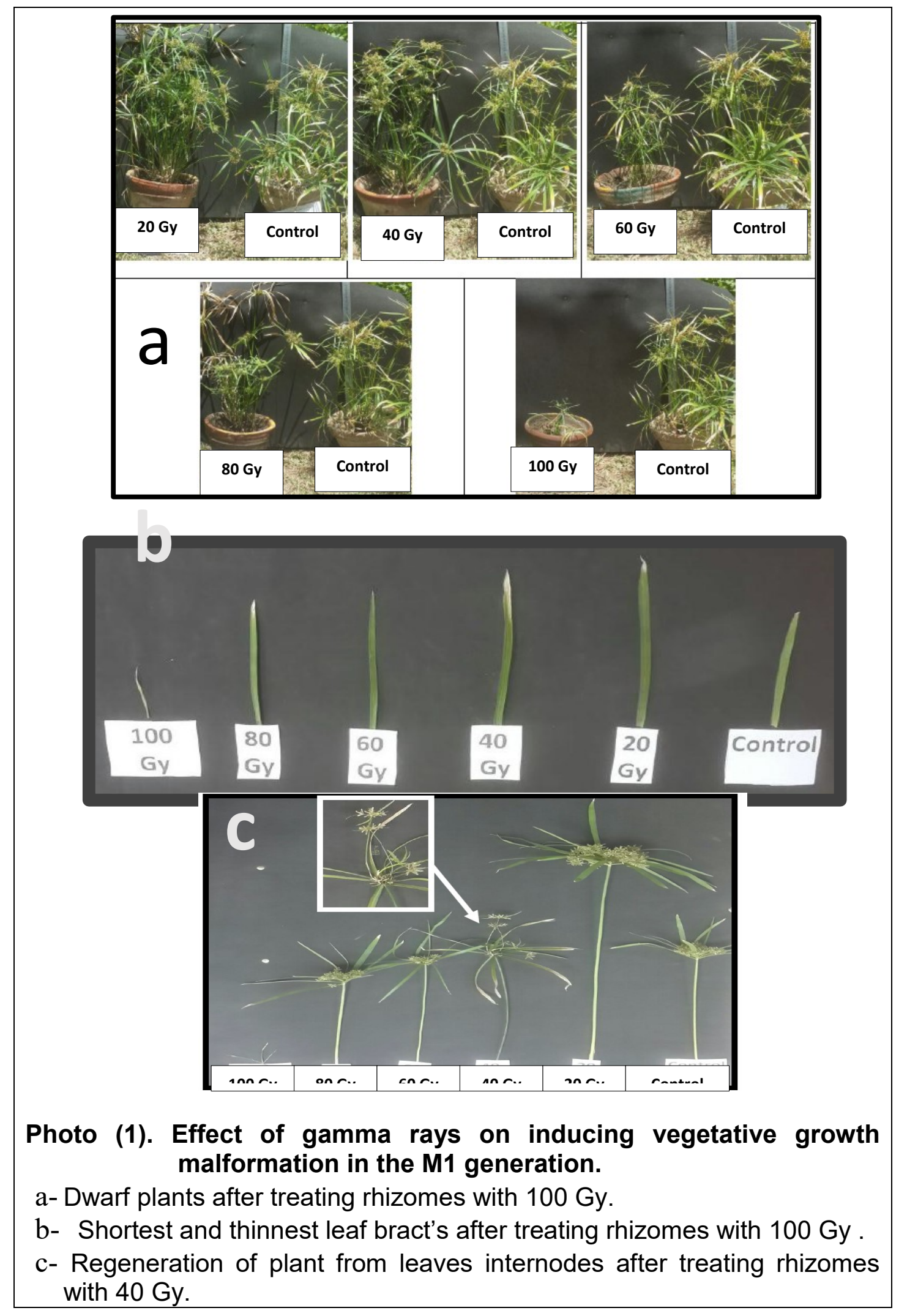


(RFLP) patterns (Figure 1). The Genetic cluster was divided into two main clusters. The first generation of Cyperus alternifolius treated with 100 Gray represented the separated first cluster. Second cluster composed of two subclusters. The First subcluster included second generation of Cyperus alternifolius control, second generation of Cyperus alternifolius treated with 60 Gray and third generation of Cyperus alternifolius treated with 100 Gray. Second sub cluster divided into two groups. Third generation of Cyperus alternifolius treated with 60 Gray and second generation of Cyperus alternifolius treated with 100 Gray represented the first group. Meanwhile, second group represented first generation of Cyperus alternifolius control, treated with 60 Gray and third generation of Cyperus alternifolius control.

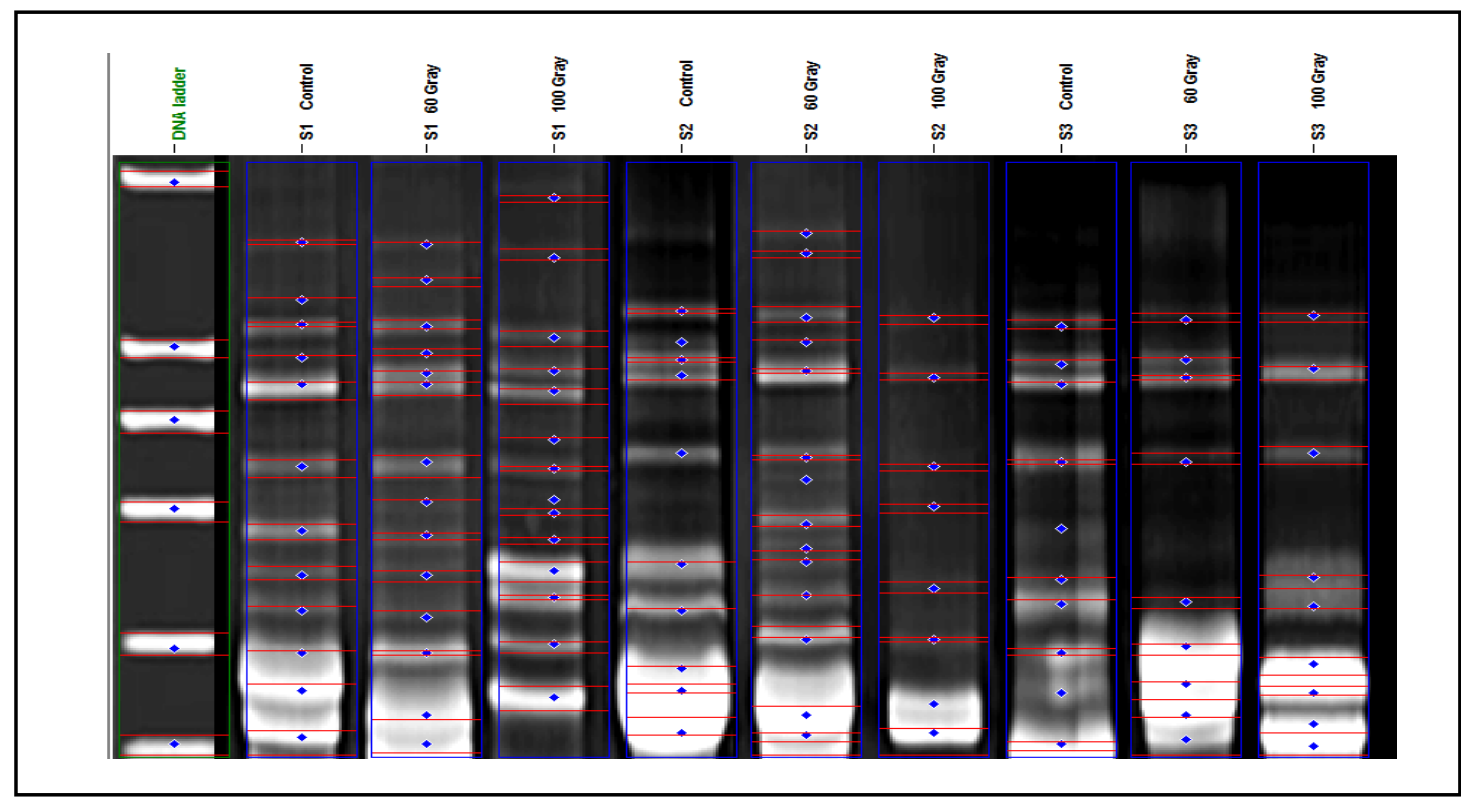

Photo (2). Computerized analysis of Restriction fragment length polymorphism (RFLP) for three generations of Cyperus alternifolius under different radiations doses.

Table (7). Different radiation doses comparison for Cyperus alternifolius treated with different radiation doses based on Restriction fragment length polymorphism (RFLP) data.

\begin{tabular}{lccc}
\hline & \multicolumn{3}{c}{$\begin{array}{c}\text { Radiation doses } \\
\text { (Gray) }\end{array}$} \\
\cline { 2 - 4 } & Control & $\mathbf{6 0}$ & $\mathbf{1 0 0}$ \\
\hline Total fragments & 32 & 36 & 31 \\
Polymorphic fragments & 12 & 16 & 20 \\
Polymorphism \% & 37.5 & 44.4 & $\mathbf{6 4 . 5}$ \\
\hline
\end{tabular}


Table (8).Total, Polymorphic, Monomorphic and Polymorphism \% for Cyperus alternifolius treated with different radiation doses based on Restriction fragment length polymorphism (RFLP) data.

\begin{tabular}{ccccccc}
\hline Seasons & $\begin{array}{c}\text { Radiation } \\
\text { doses } \\
\text { (Gray) }\end{array}$ & $\begin{array}{c}\text { Total } \\
\text { fragments }\end{array}$ & $\begin{array}{c}\text { Polymorphic } \\
\text { fragments }\end{array}$ & $\begin{array}{c}\text { Monomorphic } \\
\text { fragments }\end{array}$ & $\begin{array}{c}\text { Polymorphism } \\
\%\end{array}$ & $\begin{array}{c}\text { Average of } \\
\text { Polymorphism } \\
\%\end{array}$ \\
\hline First & Control & 12 & 6 & 6 & 50.0 & \\
Season & 60 & 14 & 5 & 11 & 35.7 & 54.8 \\
& 100 & 14 & 11 & 3 & 78.7 & \\
\hline \multirow{2}{*}{ Second } & Control & 10 & 3 & 7 & 30.0 & \\
Season & 60 & 13 & 8 & 5 & 61.5 & 47.2 \\
& 100 & 8 & 4 & 4 & 50.0 & \\
Third & Control & 10 & 3 & 7 & 30.0 & 39.6 \\
Season & 60 & 9 & 3 & 6 & 33.3 & \\
& 100 & 9 & 5 & 4 & 55.5 & \\
\hline
\end{tabular}
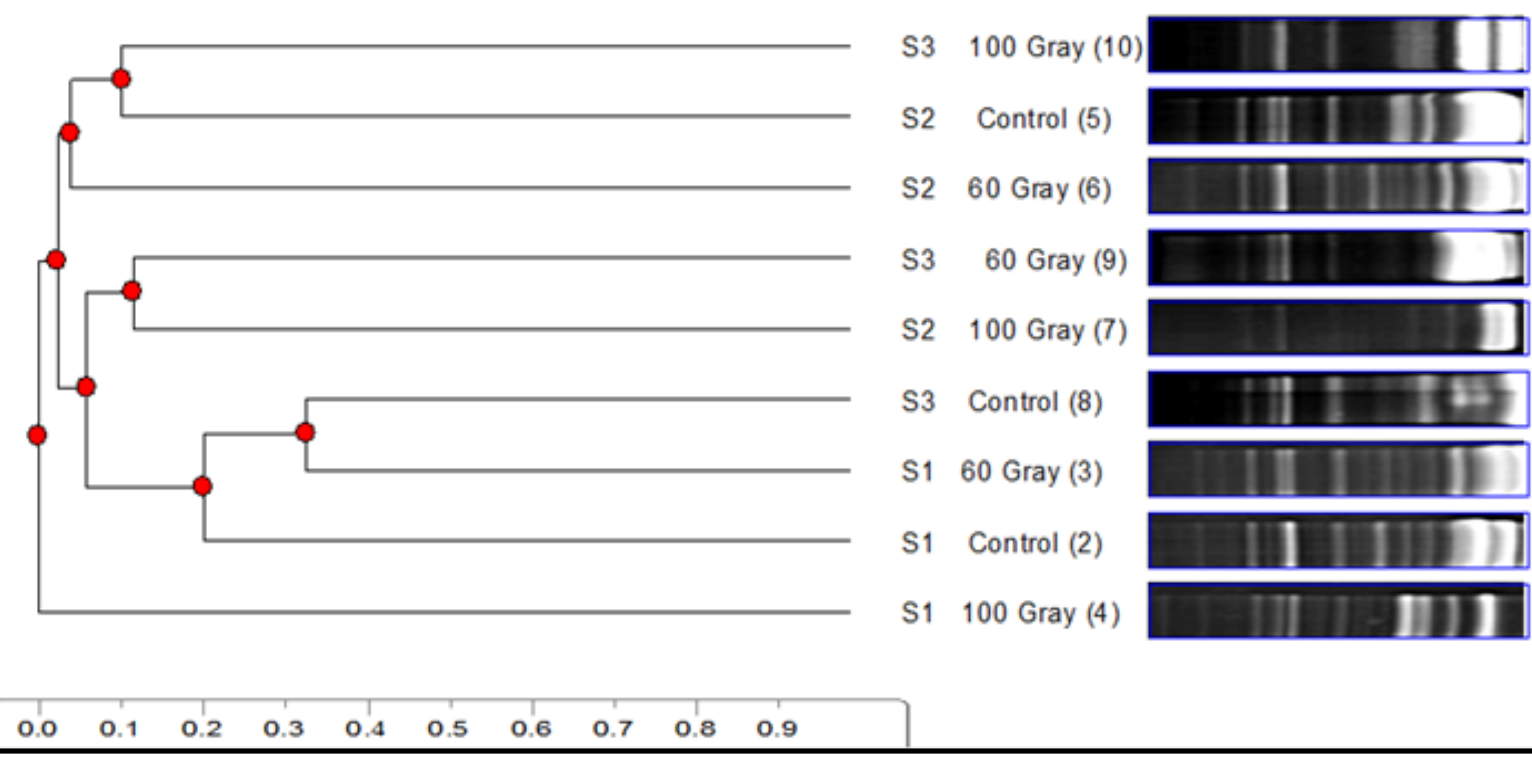

Figure (1). Phyllogenetic tree for three generations of Cyperus alternifolius treated with different radiation doses based on Restriction fragment length polymorphism (RFLP) data.

\section{DISCUSSION}

The increase in sprouting percentage and sprouting rate after rhizomes irradiation with gamma rays at 20 Gray may be due to the ability of low gamma ray doses to activate RNA or protein synthesis, which occurred during the early stage of sprouting after rhizome irradiated (Abdel-Hady et al., 2008). Also, this increment can be explained by the stimulatory effect of gamma rays on sprouting enzymes which are set free by irradiation and activate sprouting (Sax, 1955). This results are in harmony with those obtained by Anupam et al. (2018) on gladiolus 
plants. On the other hand, the harmful effect of higher doses of gamma rays on sprouting may be caused by the break down or lake of synthesis of endogenous growth regulators, especially the cytokines due to radiation Kiong et al. (2008) or the lethal effect of gamma rays on chromosome structure and cell division (Grabowska and Mynett,1970).

The stimulatory effect of gamma rays on vegetative growth can be explained by the hypothesis of Wi et al. (2007) which cleared that low doses of gamma radiation induce stimulation to plant growth by changing the signaling network of plant hormones or by increasing the antioxidative effect of the cells to increase the ability tolerant of the plant to daily stress factors such as light intensity and temperature. While, the high irradiation doses caused inhibition of plant growth by the arrest of the cell cycle at $G_{2} / M$ phase during somatic cell division or various damage of the entire genome. (Preussa and Britta, 2003), also the inhabitation effect of gamma rays at high doses on plant growth can be explained due to the physiological effect of gamma rays such as auxin destruction (Sedel'nikova, 1988).

It is also known that gamma radiation induces the various physiological and biochemical alteration in plants. The reduction effect of high gamma ray doses was recorded by Yadav (2016) on Canscora decurrens plants. The high irradiation dose caused a significant decrement in chlorophyll a content in the M1 generation this decrement may be due to the disturbance of the hormone balance, leaf gas-exchange, water exchange and enzyme activity (Kiong et al., 2008). Irradiation causes changes in the plant structure, dilation of thylakoid membranes, and alteration in photosynthesis (Wi et al., 2007). The data of (RFLP) analysis showed that there were changes in DNA bands. The main changes were the appearance or disappearance of different bands with variation of intensity and radiation dose (100 Gray) reflected the dramatic increase of genetic polymorphism. This effects might be due to the rearrangement of DNA caused by different type of DNA damage. The appearance of new bands is usually a result from different DNA structural changes (Breaks, transpositions, deletion,... etc.) (Danylchenko and Sorochinsky, 2005).

\section{REFERENCES}

Abdel-Hady, M.S., E.M. Okasha, S.S.A. Soliman and M. Talaat (2008). Effect of Gamma radiation and gibberellic acid on germination and alkaloid production in Atropa belladonna. Aust. J.Basic Appl., 2(3): 401-405.

Anupam T, Singh A. K. and P. Sumit (2018). Effect of gamma irradiation on growth and floral characters of gladiolus varieties. Int. J. of Chemical Studies, 6(6): 1277-1282

Brasch J, V. Beck-Jendroschek and R. Gläser (2010). Fast and sensitive detection of Trichophyton rubrum in superficial tinea and onychomycosis by use of a direct polymerase chain reaction. Blackwell Verlag $\mathrm{Gmb} \mathrm{H}$. :54(5):e313-7. 
Danylchenko O.and B. Sorochinsky (2005). Use of RAPD assay for the detection of mutation changes in plant DNA induced by UV-B and Rrays BMC plant. Biology, 5 (1). 812.

Dipak, K and H. Soma (2010). Plant breeding Biometry Biotechnology . New Central Book Agency (P) Ltd . London ,Delhi Kolkata

Grabowska, B. and K. Mynett(1970). Induction of changes in garden gladiolus, (Gladiolus hybridus. Hort.) under the influence of gamma rays Co60 (Russian). Biul. Instytutu Hodowii i Aklimatyzacji Roslin (IHAR), 1-2 : 85-8.

Kiong, A., A. Ling Pick, S.H. Grace Lai and A.R. Harun (2008). Physiological responses of Orthosiphon stamineus plantlets to gamma irradiation. AmEurasian J. Sustain. Agric. 2(2):135-149.

Kyambadde, J., F. Kansiime, L. Gumaelius, and G. Dalhammar (2004). A comparative study of Cyperus papyrus and Miscanthidium violaceum based constructed wetlands for wastewater treatment in a tropical climate. Water Research, 38(2):475-485.

Mirzahoseini H, E. Omidinia, M.Shams-Ghahfarokhi , G. Sadeghi and M. Razzaghi-Abyaneh (2009). Application of PCR-RFLP to rapid identification of the main pathogenic dermatophytes from clinical specimens. Iranian J. Publ Health. , 38(1):18-24.

Mahmoud, A.E.K (2013). Vegetable plants physiology. El-Maaref Publishers .Alexandria

Moran, R. ( 1982). Formula determination of chlorophyll pigment extracted with N,N diethyl formamide. Plant Physiology, $69: 1376-1381$.

Preussa, S.B. and A.B. Britta (2003). A DNA-damage-induced cell cycle checkpoint in Arabidopsis. Genetics, 164: 323-334.

Sax, K. (1955). The effect of ionizing radiation on plant growth. Amer. J. Bot., 42 : 360-364.

Sedel'nikova, L. (1988). Mutations in flower colour of gladioli from gamma irradiated corms. Byulleten' Glavnogo Botanicheskogo Sada, 148 : 55-60.

Shaw J., Lickey E. B., Schilling E. E. and R.L. Small. ( 2007). Comparison of whole chloroplast genome sequences to choose noncoding regions for phylogenetic studies in angiosperms: The tortoise and the hare III. American Journal of Botany 94: 275-288.

Snedecor, G. W. and W. Cochran (1989). Statistical Methods, $8^{\text {th }}$ ed. lowa State University Press.

Van Harten , A.M. (1998). Mutation Breeding: Theory and Practical Applications. Cambridge University Press, Cambridge, UK.

Wi, S.G., B.Y. Chung, J.S. Kim , J.H. Kim , M.H. Baek , J.W. Lee and Y.S. Kim (2007). Effects of gamma irradiation on morphological changes and biological responses in plants. Micron, 38: 553-564.

Yadav V. (2016). Effect of gamma radiation on various growth parameters and biomass of Canscora decurrens Dalz . Inter.J. of Herbal Medicine; 4(5): 109115 


\title{
الملخص العزبي
}

\section{استحداث بعض الأختلافات المورفولوجية في نبات البردي باستخدام اشعه جاما}

\author{
مجد الاين فوأد رضا \\ فرع بحوث نباتات الزينة بأنطونيادس - الإسكندرية \\ قسم بحوث الزينة وتتسيق الحدائق - معهز بحوث البساتين - مركز البحوث الزراعية
}

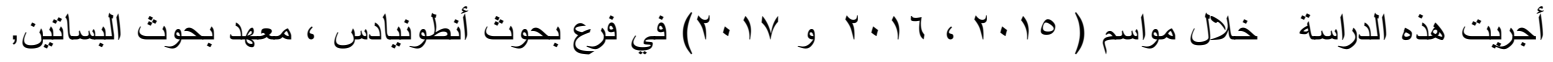
وزارة الزراعة، الاسكندرية،جمهورية مصر العربية بهدف دراسة تأثثر اشعة جاما على نبات البردي ـ عرضت ريزومات

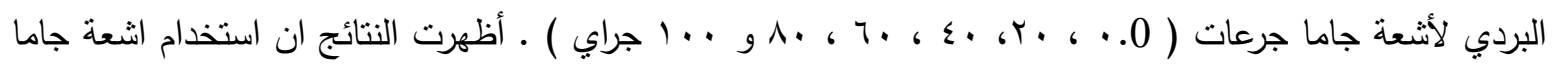

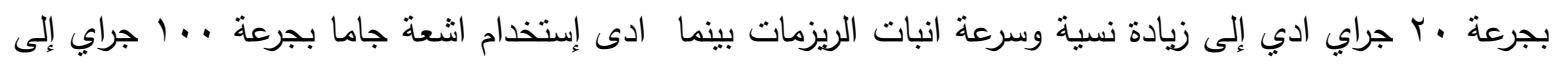

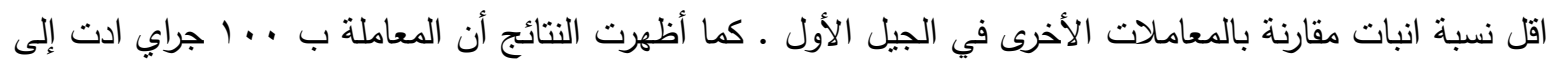
نقص معنوي في كل الصفات الخضرية المدروسة في الجيل الأول والثاني • وبالنسبة لتاثير اشعة جاما على احدات شذوذات في النمو الخضري اظهرت النتائج ان المعاملة ب. . 1 جراي ادت إلى تثزم في النباتات في الجيل الأول

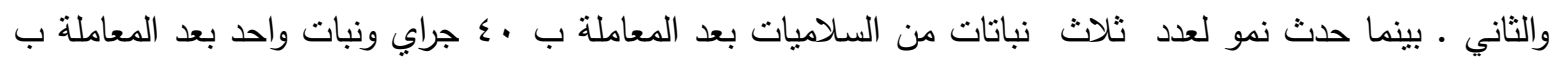

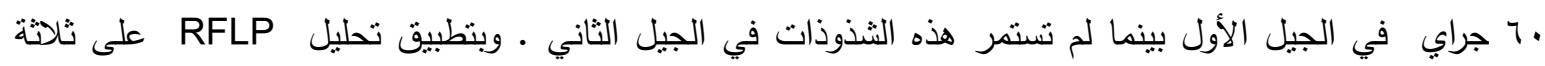

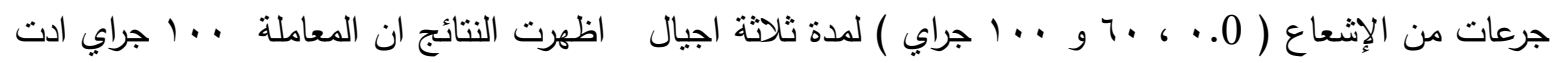
إلى زيادة في اختلافات الحامض النووي ، كذلك الجيل الأول اظهر اعلى معدل في اختلاقات الحامض النووي . 
